\title{
Effect of water content on the thermal inactivation kinetics of horseradish peroxidase freeze-dried from alkaline $\mathrm{pH}$
}

Maria Adília Lemos ${ }^{(1)}$, Jorge C. Oliveira ${ }^{(*, 2)}$ and Jorge A. Saraiva ${ }^{(3)}$

(1) Escola Superior de Biotecnologia, Universidade Católica Portuguesa, Rua Dr. António Bernardino de Almeida, 4200 PORTO, PORTUGAL

(2) Department of Food Science and Technology, University College Cork Cork, Ireland

Tel: 353-21-902748; Fax: 353-21-276398; E-mail: j.oliveira@ucc.ie

(3) Department of Chemistry, University of Aveiro

Campus de Santiago, 3810-193 AVEIRO, PORTUGAL

\section{(*) Corresponding author}

Keywords: enzyme inactivation, kinetic modeling, protein thermal denaturation

Running title: Thermal inactivation of dried peroxidase 
Thermal inactivation of dried peroxidase 


\section{Summary}

The thermal inactivation of horseradish peroxidase freeze-dried from solutions of different $\mathrm{pH}$ (8, 10 and 11.5 , measured at $\left.25^{\circ} \mathrm{C}\right)$ and equilibrated to different water contents, was studied in the temperature range 110 to $150^{\circ} \mathrm{C}$. The water contents studied $(0.0,1.4,16.2$ and $25.6 \mathrm{~g}$ water per $100 \mathrm{~g}$ of dry enzyme) corresponded to water activities of $0.0,0.11,0.76$ and 0.88 at $4{ }^{\circ} \mathrm{C}$. The kinetics were well described by a double exponential model. The enzyme was generally more stable the lower the $\mathrm{pH}$ of the original solution and for all $\mathrm{pH}$ values, the maximum stability was obtained at $1.4 \mathrm{~g}$ water/100 $\mathrm{g}$ dry enzyme. $\mathrm{z}$ values were generally independent of water content and of the $\mathrm{pH}$ of the original solution, and in the range of $15-$ $25{ }^{\circ} \mathrm{C}$ usually found in neutral conditions, with the exception of the enzyme freeze dried from pH 11.5 and equilibrated with phosporus pentoxide, where a $\mathrm{z}$ value of the stable fraction close to $10{ }^{\circ} \mathrm{C}$ was found. 


\section{Introduction}

Enzimic systems have been proposed as Time-Temperature Integrators (TTIs) for assessing thermal processes (Weng et al., 1991, Hendrickx et al., 1992, Van Loey et al., 1999). It is straightforward to note from the kinetic decay/death models that the requirements for such a system are that the $\mathrm{z}$ value of the enzymic system and of the target micro-organism are equal (equation 1), as in such case, the F-value can be determined easily, rapidly and inexpensively, by measuring the enzymatic activity before and after processing (Van Loey et al., 1996).

$$
\begin{aligned}
& \mathrm{F}=\mathrm{D}_{\mathrm{M}}\left(\log \mathrm{N}_{\mathrm{o}}-\log \mathrm{N}\right)=\int_{0}^{\mathrm{t}} 10^{\frac{\mathrm{T}-\mathrm{T}_{\mathrm{r}}}{\mathrm{z}}}=\mathrm{D}_{\mathrm{E}}\left(\log \mathrm{A}_{\mathrm{o}}-\log \mathrm{A}\right) \\
& \text { for } \mathrm{Z}_{\mathrm{M}}=\mathrm{z}_{\mathrm{E}}=\mathrm{z}
\end{aligned}
$$

where $\mathrm{N}$ is the microbial count, A the enzyme activity, $\mathrm{D}$ the thermal death time, $\mathrm{z}$ the temperature sensitivity of the D value, and the subscripts o, M and E represent initial, microbial and enzymic, respectively.

Therefore, obtaining enzymic systems with various $\mathrm{z}$ values, and particularly in the low range, typical of micro-organisms, would be most useful for developing TTIs to be used in different situations. This would entail selecting enzymes and micro-environmental factors (e.g. water content, presence of solvents, $\mathrm{pH}$ ) that result in appropriate kinetic parameters to mimic the kinetic behaviour of micro-organisms (or quality factors). However, $\mathrm{z}$ values are not easily manipulated, as they depend mostly on the inactivation mechanism, and may not vary significantly with the actual thermal resistance (which is mathematically accounted for in most cases by variations of the thermal death time). 
A factor that may cause a significant variation in the $\mathrm{z}$ value is $\mathrm{pH}$, as it may affect the relative balance between different inactivation mechanisms (Whitaker, 1972, Burnette, 1977, Lemos et al., 1999). However, $\mathrm{pH}$ variations significant enough to cause a visible change in the kinetic patterns generally decrease the enzyme's thermal resistance (Klibanov, 1995, Costantino et al., 1997). Hence, to obtain a useful system for thermal processing assessment based on $\mathrm{pH}$ variation of the enzyme system, one would need to maintain the $\mathrm{z}$-value of the thermal inactivation of enzymes at high $\mathrm{pH}$ while increasing the thermal death times, as temperatures are tipically in the range of $110-130{ }^{\circ} \mathrm{C}$.

Water is known to play a crucial role in the thermal stability of enzymes, as it participates in all non-covalent interactions (maintaining proteins in their active conformations) and also plays a very important role in enzyme dynamics (Multon \& Guilbot, 1975). In water-depleted environments, obtained by liophilisation or by replacing water by organic solvents, enzymes have shown to be much more thermostable than in solution. An increase of the thermal stability with dehydration was found for many enzymes, such as porcine pancreatic lipase (Zaks \& Klibanov, 1984), pancreatic and wheat grain ribonuclease Multon \& Guilbot, 1975), $\beta$-lactoglobulin (Ruegg et al., 1975), mioglobin (Hagerdal \& Martens (1976), $\alpha$-amylase (Meerdink \& Van't Riet, 1991, Saraiva et al., 1996a, Van Loey et al., 1996), and horseradish peroxidase (Hendrickx et al., 1992, Saraiva et al., 1996b).

Dehydrating an enzymic system by freeze drying from a solution with a different $\mathrm{pH}$ might therefore provide a suitable TTI for thermal processing applications. The prevailing question is whether the loss of water (and hence of the molecular conformation at the respective original $\mathrm{pH}$ ) will imply that the inactivation kinetics resume to their 'normal' behaviour (the kinetic parameters of enzyme dried from neutral $\mathrm{pH}$ ), or whether a so-called 'pH-memory' effect will be found, and the z-value maintains the $\mathrm{pH}$ dependency. The concept of 'pH memory”, as defined by Klibanov (1995) and explored also by Costantino et al., 1997, 
refers to enzyme systems that when in absence of water (either by dehydration of by replacing the aqueous media by organic solvents) show the same characteristics as in the original solution, as if the enzyme "remembered" in some way the conformation it had in the original pH. However, no study was found on whether this concept might be extended to the temperature sensitivity of thermal inactivation (the $\mathrm{z}$ value).

Horseradish peroxidase has been studied in the context of TTI systems, as it is one of the most thermally resistant enzymes of interest to vegetable products (frequently used to assess the efficiency of blanching processes), whose analytical assay is simple and inexpensive (Rodrigo et al., 1996). It however shows a biphasic behaviour, that is, non-log linear (Ling and Lund, 1978, Chang et al., 1988, Ganthavorn et al., 1991, Weng et al., 1991, Hendrickx et al., 1992, Guenes \& Bayindirli, 1993, Pizzocaro et al., 1993, Adams, 1997, Saraiva et al., 1996b, Rodrigo et al., 1996, 1997, Forsyth et al., 1999). The z-value of the kinetically more meaningful resistant fraction is around $15-25^{\circ} \mathrm{C}$, whether in solution or freeze dried (Hendrickx et. al., 1992, Saraiva et al., 1996b). Recently, Lemos et al. (2000), have found that horseradish peroxidase at high alkaline $\mathrm{pH}\left(11.5\right.$ to 12.5 , measured at $\left.25^{\circ} \mathrm{C}\right)$. showed low $\mathrm{z}$ values of the more thermally resistant fraction of the enzyme, around $10{ }^{\circ} \mathrm{C}$.

The objective of this work was to verify whether a pH-memory effect existed in horseradish peroxidase in relation to the $\mathrm{z}$-value, by determining the kinetic parameters of systems with different (low) water contents obtained from solutions of different $\mathrm{pH}$. The ultimate goal would be the development of a suitable TTI for thermal process assessment, should conditions be found where a $\mathrm{z}$ value of $10{ }^{\circ} \mathrm{C}$ and a high thermal resistance enable its use in industrial thermal processes. 


\section{Materials and Methods}

\section{Enzyme solution}

A $0.08 \mathrm{mg} / \mathrm{ml}$ solution of enzyme (horseradish peroxidase, Ec 1.11.1.7, RZ 0.8, Sigma, St. Louis, MO 63158, USA) in bidistilled water ( $\mathrm{pH} 7)$ was used and the $\mathrm{pH}$ of the solution was adjusted to the value desired with $\mathrm{NaOH}$ or $\mathrm{HCl}$ solutions. The $\mathrm{pH}$ at room temperature $\left(25^{\circ} \mathrm{C}\right)$ was measured using a pH meter (Crison, 2001).

In order to obtain systems with different water contents, the enzyme was lyophilised and then equilibrated for 6 days at $4{ }^{\circ} \mathrm{C}$ over standard salt solutions of phosphorus pentoxide, lithium chloride, sodium chloride and potassium chloride, respectively, at water activities $\left(\mathrm{a}_{\mathrm{w}}\right)$ of $0,0.11,0.76$ and 0.88 (Greenspan, 1977). The sorption isotherm of horseradish peroxidase at $4{ }^{\circ} \mathrm{C}$ has been reported by Hendrickx et al., 1992. The water activities of $0.11,0.76$ and 0.88 correspond to the moisture contents of $1.4,16.2$ and $25.6\left(\mathrm{~g} \mathrm{H}_{2} \mathrm{O} / 100 \mathrm{~g}\right.$ dry enzyme) at $4^{\circ} \mathrm{C}$. The inactivation experiments were performed on the seventh day.

\section{Thermal treatment}

The small glass vials were hand crimped tightly and as rapidly as possible to avoid changes in atmosphere. The closed vials containing the dried enzyme were heated in an oil bath at the desired (constant) inactivation temperature. At predetermined time intervals samples were transferred and quickly immersed in an ice bath. After cooling the vials were opened and phosphate buffer $(0.1 \mathrm{M}, \mathrm{pH} 7,625 \mu \mathrm{l})$ was added to each, the vials remaining in ice until activity assay.

It is evident that at the inactivation temperatures some water will desorb from the dry phase, increasing the pressure in the vials, which has the effect of counteracting the loss of 
water due to temperature increase. Based on comparable literature studies, it has been considered that some water does change to the gas phase, but that it is expected that the water remaining in the solid matrix is above 60-70\% (Hendrickx et al., 1992). As the amount of water at the inactivation temperatures is not known and may vary with temperature in this range, the text refers always to the amount at $4{ }^{\circ} \mathrm{C}$, knowing that the true amount during inactivation will be somewhat lower.

The inactivation temperatures were selected depending on water content and $\mathrm{pH}$, as these affect the enzyme stability. The experimental plan is shown in table 1.

\section{Activity analysis}

The peroxidase activity was measured according to the Worthington (1978) procedure. The enzyme was dissolved in bidistilled water back to the concentration of $0.08 \mathrm{mg} / \mathrm{ml}$ solution and an aliquot of $100 \mu \mathrm{l}$ of this solution was mixed with $2.9 \mathrm{ml}$ of substrate solution (0.9 mM H $\mathrm{H}_{2}(27 \%$, w/w), $83.09 \mathrm{mM}$ phenol concentration and $1.19 \mathrm{mM}$ 4-aminoantipyrine concentration, in a $0.1 \mathrm{M}$ phosphate buffer, $\mathrm{pH} 7.0$ ). The increase in optical density at $510 \mathrm{~nm}$ was measured using a Unicam 8625 UV/VIS kinetics spectrophotometer every 1 second during 1 minute, at $25^{\circ} \mathrm{C}$. The optimum conditions for this enzymatic assay suggested by Weng et al. (1991) were used, i.e. $\mathrm{pH} 7,25^{\circ} \mathrm{C}$ and ionic strength $0.1 \mathrm{M}$.

In preliminary experiments, the enzyme activity before and after lyophilisation and during several days storage above different salt solutions was measured and it was verified that these procedures did not have a significant effect on the enzyme activity. Notwithstanding, and in order to eliminate the effect of thermal lags as well, the 'zero' point for each experiment was obtained by removing samples after 5 to $6 \mathrm{~s}$ (depending on temperature) and setting then the experimental time to zero. No reactivation of peroxidase activity was found in samples stored for further 24 hours at $4{ }^{\circ} \mathrm{C}$. 


\section{Data analysis}

The kinetic pattern was biphasic, as expected, and a double exponential model was used. Different mechanistic interpretations of the thermal inactivation of enzymes generate a mathematical model that is reduced to a double exponential at isothermal conditions and thus describes the biphasic patterns: (i) the enzyme population consists of two isoenzymes, one being more labile and the other more resistant, both inactivating according to a first order decay; (ii) the inactivation mechanism involves a first step (which may be reversible) to an intermediate conformation, followed by an irreversible denaturation (Henley and Sadana, 1985). No preference was assumed for either, and for simplicity the term 'fraction' will be used throughout the text to designate the kinetic parameters of each exponential: 'more resistant fraction' means either the more resistant isoenzyme or the slower reaction step, depending on the mechanistic interpretation of the model.

Using the Thermal Death Time (TDT) model for a constant temperature, the activity at time $t$ is given by:

$$
A=A_{0}\left(\alpha 10^{-\frac{t}{D_{s}}}+(1-\alpha) 10^{-\frac{t}{D_{l}}}\right)
$$

where $A_{0}$ is the initial activity, $\alpha$ is the fractional weight of the more resistant fraction, $D_{s}$ is the thermal death time of the more resistant fraction and $D_{1}$ the thermal death time of the more labile fraction. The thermal death times are related to temperature by:

$$
D=D_{r} 10^{-\frac{T-T_{r}}{z}}
$$

where $D_{r}$ is the thermal death time at a reference temperature $\left(130^{\circ} \mathrm{C}\right.$ was chosen $)$. Assuming that $\alpha$ is independent of temperature, the parameters $\mathrm{D}_{\mathrm{r}}$ and $\mathrm{z}$ for both fractions can 
be obtained by one single regression, which is statistically preferable as the error region is smaller and well defined than with individual regressions. All sets of data for one $\mathrm{pH}$ and the several experiments at different temperatures can be fitted together to yield the five parameters $\left(\alpha, \mathrm{D}_{\mathrm{rs}}, \mathrm{D}_{\mathrm{rl}}, \mathrm{z}_{\mathrm{s}}\right.$ and $\left.\mathrm{z}_{\mathrm{l}}\right)$, by:

$$
A=A_{0}\left(\alpha 10^{-\frac{t}{D_{r s} 10^{-\left(T-T_{r}\right) / z_{s}}}}+(1-\alpha) 10^{-\frac{t}{D_{r l} 10^{-\left(T-T_{r}\right) / z_{l}}}}\right)
$$

Logarithmic regressions were used, as this improves the accuracy of the model predictions for the more meaningful stable fraction data and the homoscedasticity of the residuals. All regressions were performed with the Stata software (Stata 4.0, Stata Corporation, Texas, USA). 


\section{Results and Discussion}

Typical examples of kinetic curves are shown in figure 1. Individual analysis at each temperature (fiting each set of data taken at a single temperature separately, with equation 2 , to obtain the respective $\alpha(T), D_{r}(T)$ and $D_{l}(T)$ values) proved that $\alpha$ could be considered independent of temperature in the range tested, as assumed in equation 4 (results not shown).

The effect of the $\mathrm{pH}$ of the original enzyme solution and of water content on the fractional weight of the more resistant fraction ( $\alpha$ parameter) is shown in figure 2 . There seems to be no clear pattern, and the variability indicated could be simply due to the strong collinearity between parameters. The parameter $\alpha$ varies mostly between 0.15 and 0.2 .

Figures 3 and 4 show the effect of the $\mathrm{pH}$ of the original enzyme solution and of water content on the thermal death times of the more resistant and more labile fractions, respectively, at the reference temperature of $130{ }^{\circ} \mathrm{C}$. At all $\mathrm{pH}$ values, both thermal death times increase with the decrease in water content down to $1.4 \mathrm{~g}$ water / $100 \mathrm{~g}$ dry enzyme, showing the stabilising effect of loss of water, but for the system stripped of almost all water by the phosphorus pentoxide equilibration, the stability goes down again, to roughly the same values of the higher water content (25.6 $\mathrm{g}$ water / $100 \mathrm{~g}$ dry enzyme).

It is also evident from these figures that the enzyme stability decreases with an increase of the $\mathrm{pH}$ of the original solution (in the alkaline region). The enzyme system seems to have a 'kinetic pH-memory' effect in the sense that the stability of the system depends on the original $\mathrm{pH}$ : as an increase of $\mathrm{pH}$ in the alkaline region decreases the stability in aqueous solution (Fong and Cruess, 1929, Lopez and Burgos, 1995, Lemos et al., 2000) so we find that in freeze dried systems the enzyme is also less stable the higher the $\mathrm{pH}$ of the original solution, in the alkaline region. 
It can be seen in figures 5 and 6 that in general neither $\mathrm{pH}$ nor water content affect the z-values significantly. Most values are around $20^{\circ} \mathrm{C}$, and fluctuations within 3 to $4{ }^{\circ} \mathrm{C}$ could be eventually explained by parameter collinearity. For the more meaningful $\mathrm{z}$ value of the stable fraction, we find no 'pH-memory' effect in relation to the $\mathrm{z}$-value, in general. However, there is an important exception: when the matrix is almost depleted of water (equilibration with phosphorus pentoxide), $\mathrm{z}_{\mathrm{s}}$ decreased to a value that is not statistically different from $10^{\circ} \mathrm{C}$ at $\mathrm{pH} 11.5$, which is the value for inactivation in solution at $\mathrm{pH} 11-12$ (Lemos et al., 2000).

It appears that the absence of water and of a minimum of mobility causes a significant 'pH-memory effect' in the inactivation kinetics. This effect can be seen in the lower z-value of the more resistant fraction and in the fact that the thermal death times fall significantly from the highest values at $1.4 \mathrm{~g}$ water / $100 \mathrm{~g}$ dry enzyme to the lowest at circa $0 \mathrm{~g}$ water / $100 \mathrm{~g}$ enzyme - in principle, further dehydration should further stabilise the enzyme, and so this decrease in stability with further decrease of the water content may be associated to a better preservation of the less stable molecular arrangement of the enzyme in the high $\mathrm{pH}$ solution when all water was removed. Even a small additional amount of water (e.g. $1.4 \mathrm{~g}$ water / 100 $\mathrm{g}$ dry enzyme) is sufficient for the system to lose this "pH memory effect".

It may be noted that for all systems except the enzyme equilibrated with phosphorus pentoxide, the water content is sufficient for the system to be always above the range of glass transition temperatures typical of protein systems during thermal inactivation, but for the system that is almost stripped off of all water, inactivation may have occured in glassy state. Proteins show values of the glass transition temperature around 140 to $200{ }^{\circ} \mathrm{C}$ (Slade \& Levine, 1995). As the activation energy below glass transition is significantly higher than above glass transition, this could be a reason for the $\mathrm{z}$ value to be low at a water content of circa zero. However, if the system was below glass transition in this case, it was not reflected 
in a higher thermal stability, which glassy state should induce. Hence, the effect of glass transition, if present, was not dominant, it is the effect of $\mathrm{pH}$ on the system kinetics that prevails.

\section{Conclusion}

The stability of dried horseradish peroxidase was affected both by the $\mathrm{pH}$ of the original solution and by the water content.

When freeze-drying, the loss of water and corresponding loss of an alkaline medium re-stored the higher $\mathrm{z}$-value similar to that at neutral $\mathrm{pH}$. However, when removing almost all water by equilibrating with phosphorus pentoxide, the low z-value around $10{ }^{\circ} \mathrm{C}$ was maintained, corresponding to a ' $\mathrm{pH}$ memory effect' in the inactivation kinetics.

This work indicates a new potential TTI for sterilisation processes, with a z value not statistically different from $10{ }^{\circ} \mathrm{C}$ (temperature range tested $110-120{ }^{\circ} \mathrm{C}$ ).

\section{List of Symbols}

A - Enzyme activity $(\Delta \mathrm{OD} / \mathrm{min})$

$\mathrm{D}$ - Thermal death time; time required for one decimal log reduction - 90\% loss - of A or $\mathrm{N}$ $(\min )$

F - F-value for sterility calculations (min)

$\mathrm{N}$ - Microbial count (number of colony forming units / unit volume)

$\mathrm{z}$ - Number of degrees Celsius required for a one decimal log reduction of the thermal death time $\mathrm{D}\left({ }^{\circ} \mathrm{C}\right)$ 
$\alpha$ - Fractional weight of the more resistant fraction

\section{Subscripts:}

E - of the enzyme

$1-$ of the more labile fraction

$\mathrm{M}$ - of the target micro-organism

o - initial

$\mathrm{r}-$ at the reference temperature of $130^{\circ} \mathrm{C}$

$\mathrm{s}-$ of the more resistant fraction

\section{Acknowledgements}

The authors would like to acknowledge the financial support of the European Commission, through programme AAIR, project AIR1-CT92-0746. Author Lemos is also grateful to the Junta Nacional de Investigação Científica e Tecnológica, Portugal, for financial support.

\section{References}

ADAMS, J.B. (1997). Regeneration and kinetics of peroxidase inactivation. Food Chemistry, 60: 201-206

BuRnetTE, F. S. (1977). Peroxidase and its relationship to food flavour and quality: a review. Journal of Food Science, 42:1-6.

CHANG, B.S., PARK, K.H. \& Lund, D.B. (1988). Thermal inactivation kinetics of horseradish peroxidase. Journal of Food Science, 53: 920-923. 
Costantino, H.R., Griebenow, K., Langer, R. \& Klibanov, A.M. (1997). On the pH memory of lyophilized compounds containing protein functional groups. Biotechnology and Bioengineering, 53: 345-348

FORSYTH, J.L., APENTEN, R.K.O. \& RoBINSON, D.S. (1999). The thermostability of purified isoperoxidases from Brassica oleracea VAR gemmifera. Food Chemistry, 65 (1): 99-109.

FONG, W. \& CRUESS, W. V. (1929). The effect of $\mathrm{pH}$ on the inactivation temperature of fruit oxidase. Plant Physiology, 4: 537-541.

Ganthavorn, C., Nagel, C.W. \& Powers, J.R. (1991). Thermal inactivation of asparagus lipoxygenase and peroxidase. Journal of Food Science, 56 (1): 47-49.

GREENSPAN, L. (1977). Humidity fixed points of binary saturated aqueous solutions. Journal of Research of the National Bureau of Standards - A. Physics and Chemistry. 81A (1): 8996.

Guenes, B. \& BAyindiRli, A. (1993). Peroxidase and lipoxygenase inactivation during blanching of green beans, green peas and carrots. LWT - Food Science and Technology, 26 (5): 406-410.

HÄGERDAL, B. \& MARTENS, H. (1976). Influence of water content on the stability of myoglobin to heat treatment. Journal of Food Science, 41: 933-937.

HendrickX M., SARAiva J., Lyssens J., Oliveira J. \& TobBack P. (1992). The influence of water activity on thermal stability of horseradish peroxidase. International Journal of Food Science and Technology, 27, 33-40

Henley, J.P. \& SADANA, A. (1985). Categorization of enzyme deactivations using a seriestype mechanism. Enzyme and Microbial Technology, 7: 50-60

KLIBANOV, A.M. (1995). Enzyme memory: what is remebered and why?. Nature, 374: 596596

Lemos, M.A., Oliveira, J.C., VAn Loey, A. \& HendrickX, M.E. (1999) Influence of pH and high pressure on the thermal inactivation kinetics of horseradish peroxidase. Food Biotechnology, 13:13-32

Lemos, M.A., OliveIRA, J.C. \& SARAIVA, J.A. (2000). Influence of pH on the thermal inactivation kinetics of horseradish peroxidase in aqueous solution. Submitted to $L W T$ Food Science and Technology.

LING, A.C. \& LUND, D.B. (1978). Determinating kinetic parameters for thermal inactivation of heat resistant and heat labile isoenzymes from thermal destruction curves. Journal of Food Science, 43: 1307-1310 
LOPEZ, P. \& BuRgOS, J. (1995). Peroxidase stability and reactivation after heat treatment and manothermosonication. Journal of Food Science, 60: 451-455.

MEERDINK, G. \& VAN'T RIET, K. (1991). Inactivation of a thermostable $\alpha$ - amylase during drying. Journal of Food Engineering, 14:83-102.

Multon, J. L. \& Guilbot, A. (1975). Water activity in relation to the thermal inactivation of enzymic proteins. In: Water Relation of Foods, Duckworth, R.B. (Ed.), London, U.K.: Academic Press Inc., pp 379-396.

Pizzocaro, F., Aggujaro, R. \& Bertolo, G. (1993). Kinetics of enzyme inactivation in carrot disks during blanching. Rivista di Scienza dell'Alimentazione, 22 (3): 279-285.

Rodrigo, C., Rodrigo, M., Alvarruiz, A. \& Frigola, A. (1996). Thermal inactivation at high temperatures and regeneration of green asparagus peroxidase. Journal of Food Protection, 59 (19): 1065-1071.

Rodrigo, C., Alvarruiz, A., Martinez, A., Frigola, A. \& Rodrigo, M. (1997). High temperature short time inactivation of peroxidase by direct heating with a five channel computer controlled thermoresistometer. Journal of Food Protection, 60: 967-972.

RÜEGG, M., Moor, U. \& BlanC, B. (1975). Hydration and thermal denaturation of $\beta$ lactoglobulin: a calorimetric study. Biochemica et Biophysica Acta, 40:334-342.

Saraiva, J., Oliveira, J., Lemos, A., and HendrickX, M. (1996). Analysis of the kinetic patterns of horseradish peroxidase thermal inactivation in sodium phosphate buffer solutions of different ionic strength. International Journal of Food Science and Technology, 31: 223-231.

SARAiva, J., Oliveira, J.C., Oliveira, S., \& HENDrickX, M. (1996b). Inactivation kinetics of horseradish peroxidase in organic solvents of different hydrophobicity at different water contents. International Journal Food Science and Technology, 31: 233-240.

Slade, L. \& LEVINE H. (1995). Glass transitions and water-food structure interactions. Advances in Food and Nutrition Research, 38, 103-269

Van Loey, A., Hendrickx, M., De Cordt, S., Haetjens, T., \& Tobback P. (1996). Quantitative evaluation of thermal processes using time temperature integrators. Trends in Food Science and Technology, 7: 16-26.

Van Loey, A., Haentjens, T., Smout, C. \& HendrickX, M. (1999). Enzymic timetemperature integrators for the quantification of thermal processes in terms of food safety. In: "Processing of Foods: Quality Optimisation and Process Assessment", Oliveira, F.A.R. \& Oliveira, J.C. (Eds.). Boca Raton, FL, USA: CRC Press, pp. 13-40. 
Weng Z., Hendrickx M., Maesmans G. \& TobBack P. (1991). Thermostability of soluble and immobilized horseradish peroxidase. Journal of Food Science, 56: 574-578.

WHITAKER, J. R. (1972). General characteristics of enzymes. In: Principles of Enzymology for the Food Sciences. New York, USA: Marcel Dekker, pp 8-12.

WORTHINGTON BIOCHEMICAL CORPORATION. (1978). Enzymes and related biochemicals. Bedford, U.K.: Millipore Corporation, pp . 145-146

Zaks, A. \& Klibanov, A.M. (1984). Enzyme catalysis in organic media at $100{ }^{\circ}$ C. Science, 224:1249-1251 
Table 1 - Inactivation temperatures

\begin{tabular}{|c|c|c|c|c|c|c|c|c|c|c|c|}
\hline $\mathrm{pH}$ & \multicolumn{4}{|c|}{8} & \multicolumn{1}{c|}{10} & \multicolumn{3}{c|}{11.5} \\
\hline $\mathrm{w}^{*}$ & 0.0 & 1.4 & $\begin{array}{c}16 . \\
2\end{array}$ & $\begin{array}{c}25 . \\
6\end{array}$ & 0.0 & 1.4 & $\begin{array}{c}16 . \\
2\end{array}$ & $\begin{array}{c}25 . \\
6\end{array}$ & 0.0 & 1.4 & $\begin{array}{c}16 . \\
2\end{array}$ \\
\hline & & & & & & & & & 110 & & \\
& & & & & & & & & 115 & & 115 \\
& & & & & 120 & & & & 120 & 120 & \\
$\mathrm{~T}$ & & & & & 125 & & & 125 & & & 125 \\
$\left({ }^{\circ} \mathrm{C}\right)$ & & & & 130 & & & & & 130 & 130 \\
& 140 & & 140 & 140 & & 140 & 140 & 140 & & & \\
& & 145 & 145 & 145 & & & 145 & & & & \\
& 150 & & 150 & 150 & & 150 & & & & & \\
& 155 & 155 & 155 & & & & & & & & \\
\hline
\end{tabular}

* in $\mathrm{g}$ water / $100 \mathrm{~g}$ dry enzyme 
Figure 1 - Thermal inactivation of horseradish peroxidase with a water content of $0.0 \mathrm{~g}$ water / $100 \mathrm{~g}$ dry enzyme, obtained from a solution of pH 11.5. Experimental data and model curves for: $\triangle 110{ }^{\circ} \mathrm{C}, 0115{ }^{\circ} \mathrm{C}$ and $\square 120^{\circ} \mathrm{C}$

Figure 2 - Effect of water content and pH on the fractional weight of the resistant fraction $(\alpha) \mathbf{p H}$ of the original solution: $\square$ 8; $\square$ 10; $\square 11.5$ The bars indicate the $95 \%$ individual confidence interval.

Figure 3 - Effect of water content and $\mathrm{pH}$ on the thermal death time of the more resistant fraction at $130{ }^{\circ} \mathrm{C}\left(\mathrm{D}_{\mathrm{rs}}\right)$. The bars indicate the $95 \%$ individual confidence interval. pH of the original solution: $\square$ 8; $\square 10 ; \square 11.5$.

Figure 4 - Effect of water content and $\mathrm{pH}$ on the thermal death time of the more labile fraction at $130{ }^{\circ} \mathrm{C}\left(\mathrm{D}_{\mathrm{rl}}\right)$. The bars indicate the $95 \%$ individual confidence interval. $\mathbf{p H}$ of the original solution: $\square \mathbf{8}$; $10 ; \square 11.5$

Figure 5 - Effect of water content and $\mathrm{pH}$ on the $\mathrm{z}$ value of the more resistant fraction $\left(\mathrm{z}_{\mathrm{s}}\right)$. pH of the original solution: $\square \quad \mathbf{8} ; \square \quad \mathbf{1 0}$;

11.5. The bars indicate the $95 \%$ individual confidence interval.

Figure 6 - Effect of water content and $\mathrm{pH}$ on the $\mathrm{z}$ value of the more labile fraction $\left(z_{1}\right) . \quad$ pH of the original solution: $\square 8$; $\square$ 10; $\square$ 11.5. The bars indicate the $95 \%$ individual confidence interval. 


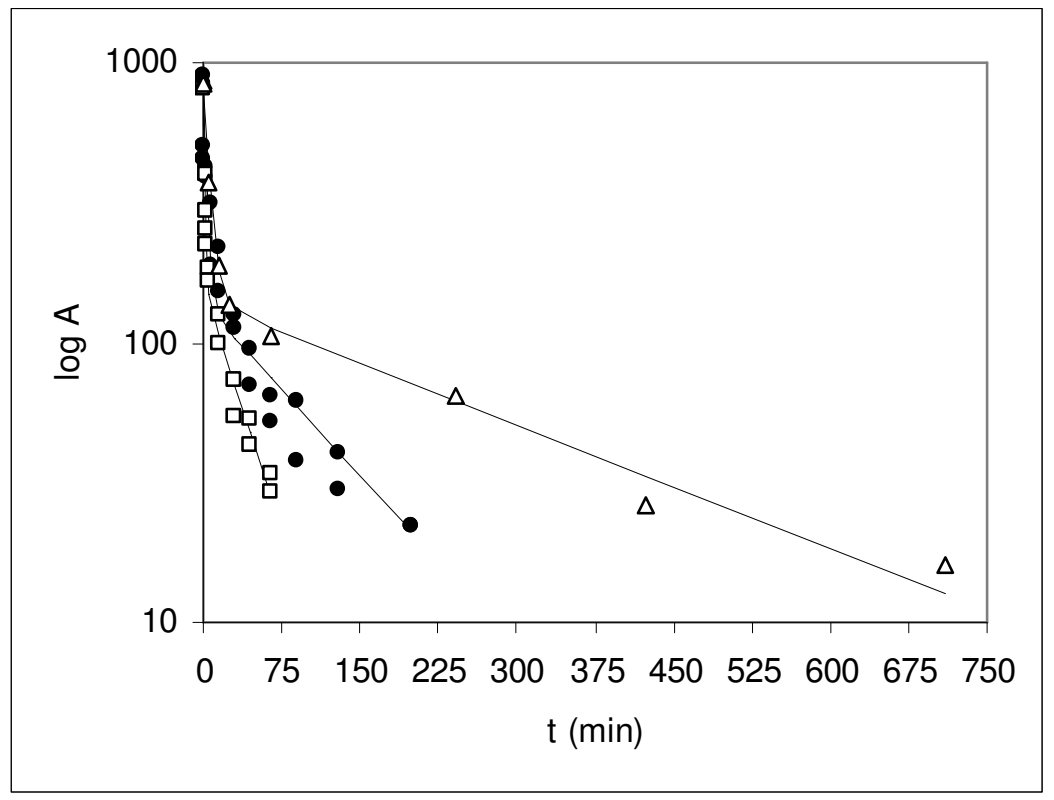

Figure 1 


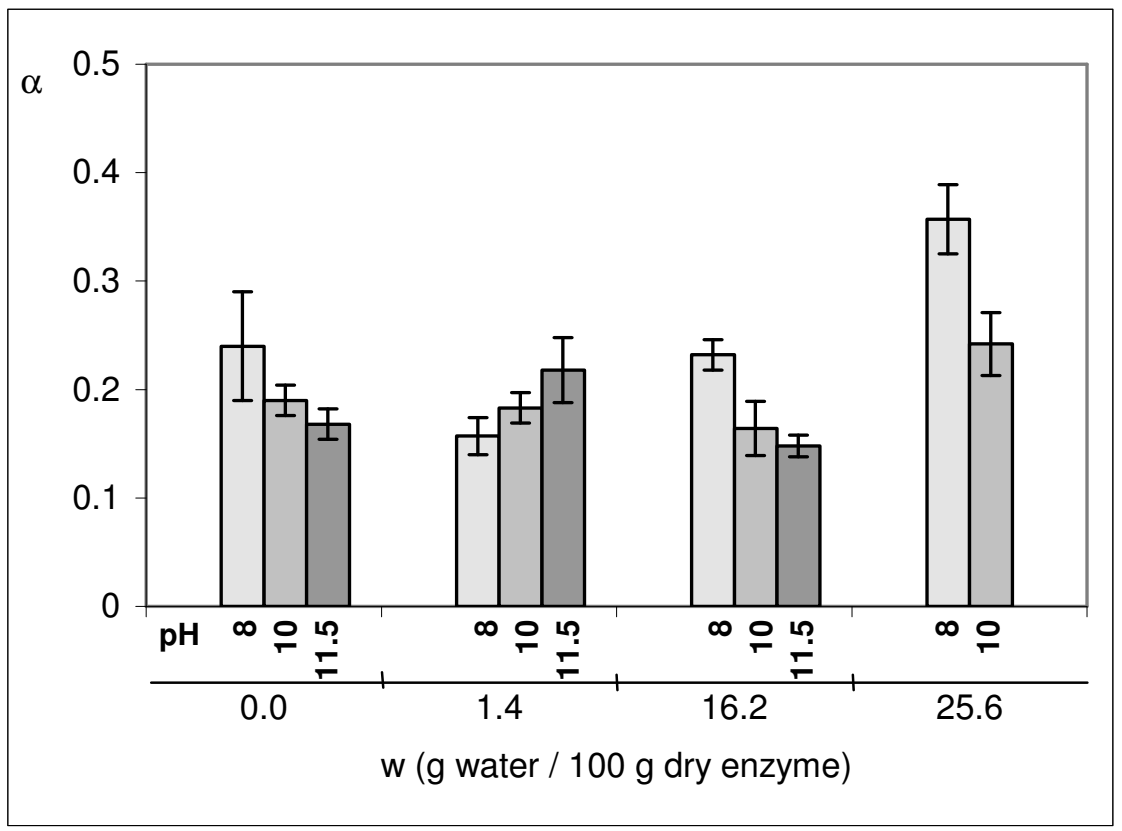

Figure 2 


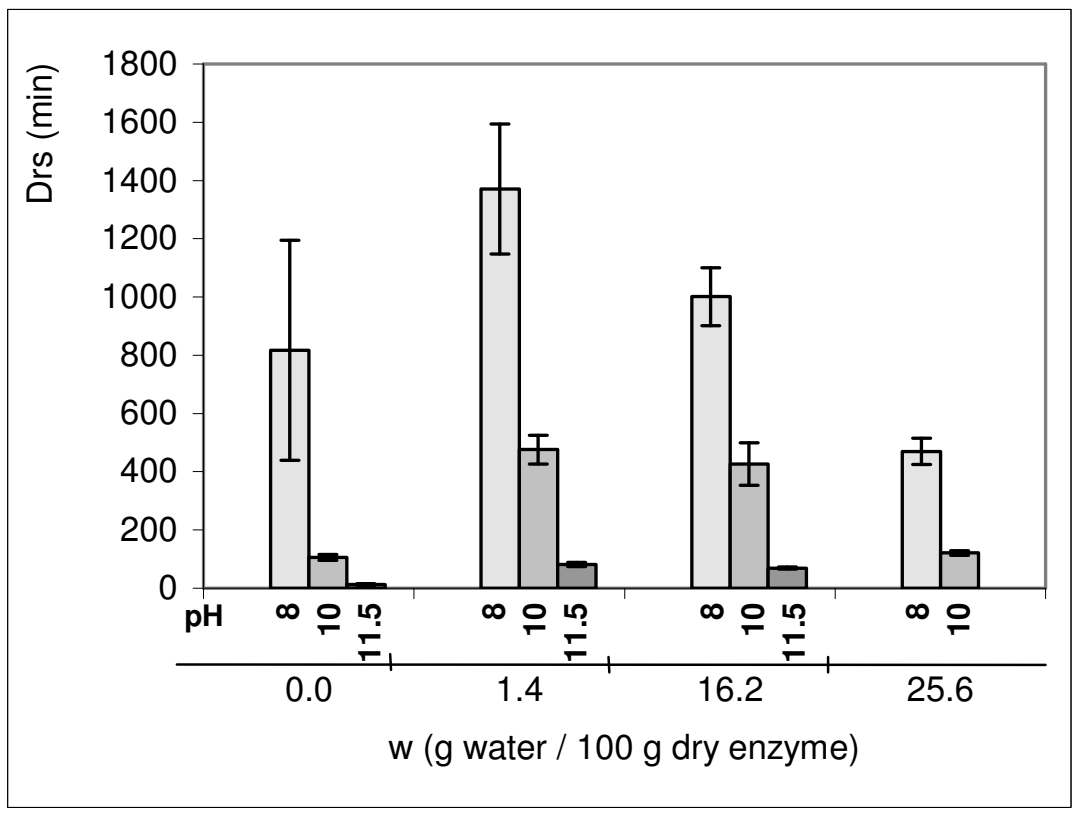

Figure 3 


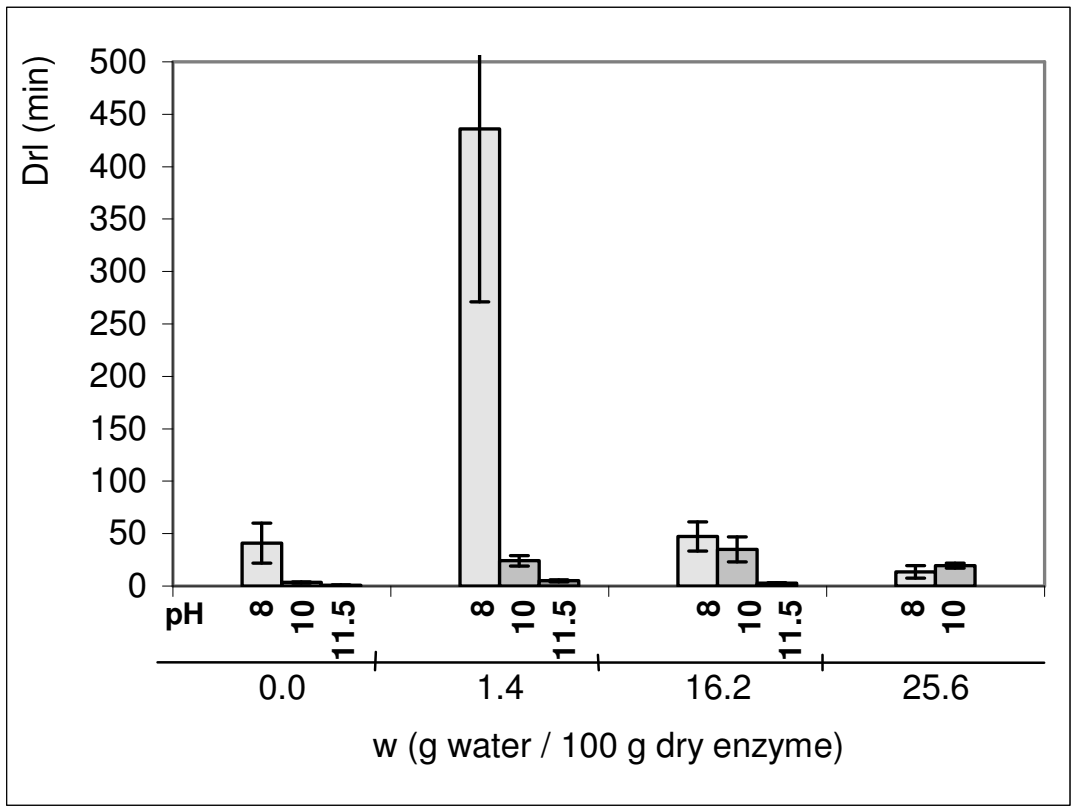

Figure 4 


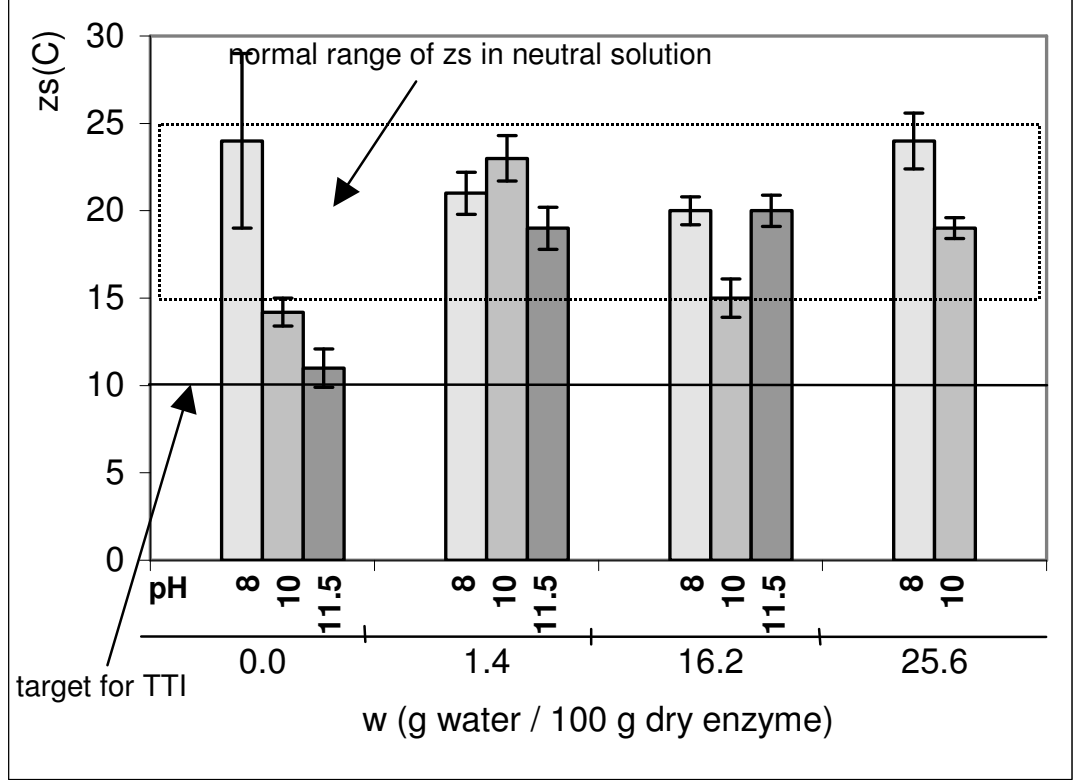

Figure 5 


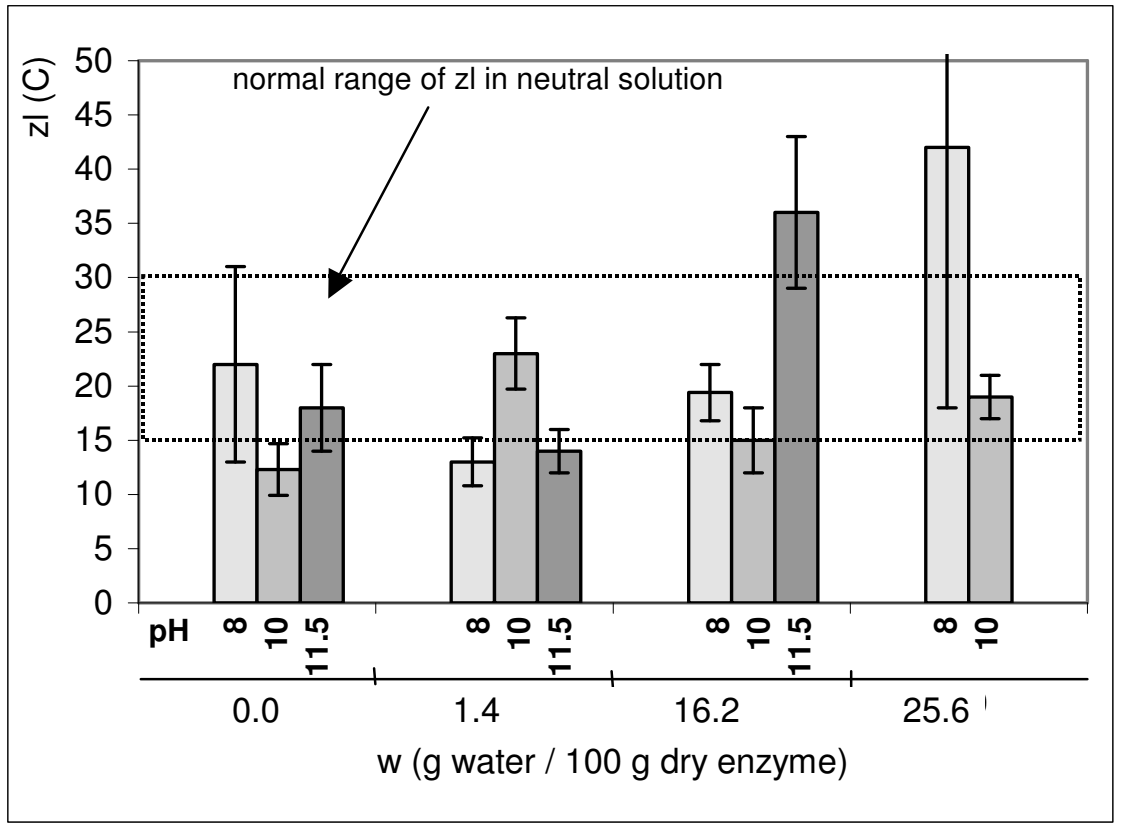

Figure 6 